Веремчук О. О.* (КНУ ім. Т.Шеъченка)

\title{
МІСЦЕ ТА РОЛЬ МОВНОГО ПИТАННЯ У ВИБОРЧІЙ КАМПАНІї 2019 Р. В УКРӒ̈НI
}

\section{THE PLACE AND ROLE OF THE LANGUAGE ISSUE IN THE ELECTION CAMPAIGN OF 2019 IN UKRAINE}

\begin{abstract}
*Olha Veremchuk - lawyer, psychologist, member of the Ukrainian Union of Psychotherapists, Taras Shevchenko National University of Kyiv (60, Volodymyrska Street, Kyiv, Ukraine).
\end{abstract}

\section{Abstract}

The article displays the problems of the language issue in political discourse, its relevance, and place in the election programs of candidates in the 2019 elections. The situation that has developed around the language policy in previous years and its place in the electoral programs in 2019 was analyzed. Such categories as "electoral technologies", "language policy", and "election program" are considered. It was found out that in connection with the regular elections of the President of Ukraine, which are held in extremely unstable circumstances, the problem of the state language policy is becoming topical again. Despite the tectonic shifts that the whole Ukrainian society has felt in recent years, the language issue has not yet disappeared from the agenda of Ukrainian politics. However, due to the fact that since 2014, Ukraine has suffered many losses and painful changes, against the background of socio-economic problems, economic issues, tariffs reduction, and war have come to the fore in political discourse. But the language issue still does not lose its position and occupies key places in a number of programs of a number of candidates for the post of President of Ukraine. It is revealed that the majority of candidates try to avoid talking about the language, or limit themselves to general statements about the "rights of citizens" and "protection of the Ukrainian language". However, there are candidates who pose the "language issue" as one of the key ones in their programs. It was concluded that, nevertheless, for the majority of candidates who come up with programs for changes in the state language policy, raising the problem of the language is most likely just a certain 
way of positioning itself within the framework of the coordinate system traditional for Ukraine. The main means of influencing the language situation in the country could be a renewed and rational language policy that would provide attractiveness to the state language and would not be forced.

Keywords: language policy, language question, electoral technologies, election campaign, candidate's election programs.

Постановка проблеми. У зв'язку із черговими виборами Президента України, які проходять у вкрай нестабільних обставинах, проблема державної мовної політики знов стає актуальною. Не зважаючи на зміни, що відбувались в країні, мовне питання все ж таки залишається ключовим в передвиборчому дискурсі, хоча на перший план виходять питання економіки, зниження тарифів та, перш за все, війни. У статті на основі аналізу програм кандидатів на пост Президента України розглянуто ситуацію, що склалася навколо мовного питання на виборах Президента України 2019 року та визначається, яке вирішення даного питання пропонують кандидати.

Мета даної статті полягає у висвітленні місця та ролі мовного питання в політичному дискурсі на виборах Президента України 2019 року.

Аналіз основних досліджень та публікацій. Розв'язанням проблем формування та реалізації державної й зокрема мовної політики в різних сферах життєдіяльності переймаються закордонні дослідники, зокрема Р. Белл, Н. Браун, І. Дрювіте, Р. Каплан, Н. Касаткіна, Я. Матрас, I. Попеску, Р. Портер, Б. Спольскі, А. Шайкевич та ін. Серед вітчизняних фахівців 3 даної проблематики варто назвати Д. Власенка, М. Козюбру, В. Нагорного, О. Копиленка, С. Гнатюка, Ф. Кирилюка, Г. Ковальчука, С. Марасюка, В. Семенова та ін.

Одним з пріоритетних напрямків державної політики кожної демократичної держави є функціонування мови титульної нації та мов національних меншин, захист їх мовних прав в усіх сферах культурного, політичного, економічного життя. Здобувши незалежність, як і країни, які стали суверенними, але й досі не позбулися політичного та культурного тиску колишніх метрополій, Україна постала перед необхідністю побудови найкращої прийнятної державної мовної політики, що виступає важливим інструментом державотворення та підтвердженням шляху незалежного розвитку. У розгляді різних моделей, стратегій та методів здійснення мовної політики, слід враховувати, що питання мовної належності безпосередньо пов'язано 
з культурно-етнічною ідентифікацією громадян, а мова виступає інструментом політики.

Мовна політика України є досить розбіжною з реальним мовним становищем у суспільстві. Вона не забезпечує соціального престижу державної мови та реалізацію їі суспільних функцій. Основна причина такого стану речей не тільки у відсутності дієвого державного механізму регулювання мовного питання, а й у тому що нормалізації мовної ситуації в Україні заважає надмірна політизація мовного питання. Проблематика визначення та здійснення державної мовної політики актуалізована на сьогодні необхідністю вдосконалення національного законодавства, імплементації міжнародно-правових норм і стандартів в галузі прав і свобод людини, зміни цілей, напрямків, завдань та пріоритетів в реалізації мовної політики.

Який же зміст містить у собі таке поняття як «мовна політика»? Аналізуючи літературу, ми можемо побачити, що дане поняття є неоднозначним. Так, найчастіше його синонімами є такі поняття як «мовне будівництво» та «мовне планування». У найбільш загальному вигляді «мовна політика» інтерпретується як комплекс цілей та принципів, що визначають регулювання мовних практик у різних сферах життя держави й суспільства, а також сукупність правових, адміністративних та господарських механізмів, через які здійснюється згадане регулювання (Борухович, 2010, с. 9).

Втім, навряд чи в сучасному світі існує держава, усі громадяни якої розмовляють тільки однією мовою. Тому в кожній країні на різних рівнях політичних та адміністративних рішень постає необхідність визначення статусу різних мов. Який же статус має українська мова та яке місце посідає у ії власній державі? Найголовнішим документом, що визначає статус мови в Україні є Конституція. Відповідно до статті десятої Конституції України «державною мовою в Україні є українська мова. Держава забезпечує всебічний розвиток і функціонування української мови в усіх сферах суспільного життя на всій території України. В Україні гарантується вільний розвиток, використання і захист російської, інших мов національних меншин України. Держава сприяє вивченню мов міжнародного спілкування. Застосування мов в Україні гарантується Конституцією України та визначається законом». Ця норма була підкріплена відповідним рішенням Конституційного Суду у грудні 1999 р. У 1997 р. Вийшла Постанова Кабінету Міністрів України «Про затвердження Комплексних заходів щодо всебічного розвитку і функціонування української мови». 
Окремі спроби зміцнення державної мовної політики були зроблені 2006 року. Указом Президента України № 625/2006 від 18 липня 2006 року було створено Раду з питань етнополітики, до компетенції якої входило формування та реалізація державної етнонаціональної політики, сприяння консолідації та розвитку української нації, iï історичної свідомості, традицій і культури, а також розвитку етнічної, культурної, мовної та релігійної самобутності національних меншин України. Крім цього, Президент України видав указ від 15 лютого 2010 року № 161/2010 «Про державну мовну концепцію». Ця концепція визначала, що пріоритетом державної мовної політики має бути утвердження і розвиток української мови, повага до української мови та мов національних меншин, а будь-які прояви зневаги є неприпустимими. У 2012 р. був ухвалений Закон України «Про засади державної мовної політики», який викликав багато сперечань та втратив свою чинність за Рішенням Конституційного Суду у 2018 році після подій 2014 року. Після був прийнятий до обговорення Проект Закону «Про забезпечення функціонування української мови як державної», який обговорюється по теперішній день, зазнає змін та поправок.

Незважаючи на те, що в Україні українська мова є державною, мова міжетнічного спілкування в багатьох районах $є$ різноманітною. Сучасна Україна є, за світовими стандартами, достатньо мононаціональною державою, де українці складають майже три чверті всього населення. Проте наша держава залишається мовно, культурно й ідеологічно неоднорідною. Незважаючи на те, що з дати проголошення незалежності України минуло 27 років, дискусії щодо мовної моделі, яка була б припустимою для нашої держави, не вщухають.

Більшість вітчизняних фахівців поділяють думку Г. Свсєєвої, згідно якої «на певних історичних етапах українці мали тісні контакти з іншими етносами, що кожного разу залишало свій відбиток в традиційній культурі, мові, антропології, менталітеті тощо. Історія українського народу не раз перетиналася з історією інших етносів, зокрема польського, російського, європейського, кримськотатарського, але вчені досі не мають цілісного образу українського суспільства в його історичній ретроспективі. Таким чином, історія України постає як конгломерат мало пов'язаних між собою етнічних спільностей» (Свсєєва, 2009, с.3-4).

Вивчення історичного розвитку суспільно-політичних та економічних процесів України в минулому може дати відповіді для вирішення багатьох сучасних проблем, у тому числі й мовної проблеми 
В. Семенов у своєму дослідженні «Історичні витоки мовної регіоналізації України» відмічає, що колонізація Південної та Східної України у XVIII-XIX століттях мала наслідком виникнення мовних розбіжностей між українськими регіонами (Семенов,2010, с. 204-209). Взагалі, за часів існування України як складової чужих імперій обмеження або й прямі заборони української мови виступали в якості державної політики, спрямованої на ліквідацію всякої самостійності та своєрідності українства. Таким чином, «складність сучасної мовної ситуації в Україні є логічним наслідком довготривалої боротьби, яка велась з українською ідентичністю, державністю, мовою спершу Російською імперією, згодом Радянським Союзом. Невпинний процес витіснення української мови з більшості сфер іії існування, знищення української еліти, асиміляція населення так і не змогли завадити їй отримати державне визнання» (Власенко, 2018, с. 3).

Не зважаючи на тектонічні зрушення, які останніми роками відчуло на себе все українське суспільство, мовне питання, на жаль, все ще не зникло із порядку денного української політики. І сьогодні воно займає одне з ключових місць у передвиборчому дискурсі 2019 року.

Задля досягнення поставленої мети у даній статті, розглянемо мовне питання у контексті структури передвиборчої кампанії та його відображення в програмах кандидатів.

Теоретикам та практикам від політики добре відомо, що «демократичні вибори в органи політичної влади в сучасному суспільстві являють собою великий соціально-політичний захід, основна мета якого - легітимне відтворення відносин громадського представництва в системі державного керівництва та управління. Як і будь-який захід, в роботі якого бере участь велика кількість людей, що виконують різні функції, вибори вимагають певного набору узгоджених за часом і місцем проведення політичних, правових і організаційних дій, одним словами - виборчих технологій, які лежать в основі розробки та втілення виборчих кампаній» (Кирилюк, 2004, с. 590).

В науковій літературі надається наступне визначення цьому поняттю: «виборчі технології - це система заздалегідь продуманих, запланованих, а також спонтанно використовуваних заходів, планів, процедур, технічних та інформаційних засобів для забезпечення успішного висунення кандидатів та їх обрання. Це також сукупність засобів і методів впливу на виборців, заснованих на відповідних наукових розробках, даних соціологічних досліджень у поєднанні 3 по- 
літичною рекламою і методами, що спрямовані на досягнення успіху на виборах певною політичною силою» (Халипов,1993, с. 304).

Виборчі кампанії, незалежно від типу виборів опираються на виборчі технології та мають однакові основні етапи, межі яких визначені політичними подіями. Якщо розглянути участь у виборах 3 позиції кандидата, можна виділити зроблені ним і його командою ряд певних кроків, які складають процедуру виборчої кампанії. Для кожного політика немислимо вступ в передвиборну боротьбу без аналізу як потреб виборців, так і своїх можливостей. Варто, щоправда, відзначити, що не завжди метою участі кандидатів у виборах $є$ перемога. Для деяких кандидатів участь у виборчих кампаніях являє собою перевірку своїх ініціатив, програм, особистих якостей, піар та ін. I саме це може істотному ступені відрізняти один від одного завдання та виборчі стратегії кандидата.

У політичній теорії вважається, що передвиборча програма є одним з основних ресурсів виборчої кампанії. Програма кандидата відноситься до обов' язкових документів виборчої кампанії. Вона подається до виборчої комісії при реєстрації кандидата та представляє собою документ, у якому сформульовані концепція і засоби, за допомогою яких кандидат, що претендує на обрання в органи влади, представлятиме інтереси виборців.

Передвиборча програма повинна складатися з наступних розділів:

1.Констатація існуючих проблем, з обов'язковими цифровими показниками, якщо мова йде, наприклад про соціальну сферу чи економічну ситуацію.

2. Основні заходи щодо вирішення цих проблем, які необхідні, на думку кандидата.

3. Окреслення перспектив розвитку країни.

Гарна, обгрунтована і позитивна програма, яка орієнтована на конкретні потреби країни дозволяє згуртувати навколо кандидата населення, створити команду однодумців, що є необхідним для успіху та може привести до перемоги. Приваблива виборча платформа і програма логічно випливають з основної теми та ідеї кампанії, які лежать у фундаменті виборчої програми. Основна тема кампанії повинна виходити за рамки позицій з конкретних питань, висловлюючи фундаментальні переконання і прагнення кандидата. Основна ж ідея передвиборної кампанії повинна відповідати наступним характеристикам: бути лаконічною; бути реалістичною; представлятися 
важливою для повсякденного життя виборців цільової групи кандидата; чітко контрастувати 3 концепцією опонентів; звертатися до серця виборців, впливати на їх емоційну сферу; розроблятися спеціально для цільової групи; бути придатною для багаторазового повторення.

Виходячи 3 цього об'єктами, на які направлена кампанія та дії політичних технологій стає широкий загал, тобто всі, хто підпадає під визначення виборця. Але чи існує сьогодні межа між політичною діяльністю, політичним впливом та маніпуляціями? Припустимо, що об'єктами маніпуляції громадяни стають унаслідок ускладнення суспільного життя, величезної кількості інформації, яка тисне на людину, суспільних суперечностей, соціальної нерівності, жорсткої соціальної стратифікації, нерівномірності й несправедливості в розподілі благ та багатства в суспільстві. I більшість цих явищ залишаються без раціонального і зрозумілого пояснення.

У сучасному світі формування громадської думки стає загальноприйнятим способом завоювання і утримання влади. Суспільство, як відомо з курсу загальної психології, ділиться на провідних і ведених, тому внутрішня суть виборчих компаній полягає в самореалізації одних людей - як лідерів, що пропонують певні ідеї і програми, - i інших, що бажаючих або не бажають приймати їх (Бабицкий, 2007, с. 4). І на цьому шляху використовується різноманітна палітра засобів. Серед них - звернення у передвиборчому дискурсі до мовного питання. Не випадково, у ряді передвиборчих компаній екс-президентів минулих років саме мовне питання займало ключові позицій. Воно традиційно було іє досі одним з важливих в українській політиці, навколо нього і потеперішній час виникає багато сперечань.

Втім у зв язку з тим, що з 2014 року Україна зазнала багато втрат та болючих змін, на тлі соціально-економічних проблем на перший план у передвиборчому дискурсі виходять питання економіки, зниження тарифів та перш за все війни. Але мовне питання все ще не втрачає своїх позицій і займає ключові місця в ряді програм низки кандидатів на посад Президента України. Спробуємо на основі контент-аналізу передвиборчих програм відповісти на питання: яка ж саме ситуація склалася навколо мовного питання в виборчих програмах та як пропонують вирішувати «мовне питання» кандидати на пост Президента України?

Варто відзначити, що більшість 3 кандидадтів намагаються уникати розмов про мову, або обмежуватися загальними висловлюван- 
нями, про «права громадян» та «захист української мови». Однак є низка кандидатів, які ставлять «мовне питання» одним 3 ключових у своїх програмах.

Так, Р. Кошулинський обіцяє: «Забезпечити українській мові реальний статус єдиної державної. Зобов' язати всіх держслужбовців вживати українську мову на роботі та під час публічних виступів. Запровадити обов' язковий іспит з української мови для держслужбовців та кандидатів на виборні посади. Позбавити ліцензій 3MI, які порушують мовне законодавство, принижують національну гідність українців, поширюють дезінформацію або ведуть антиукраїнську пропаганду. Скасувати оподаткування на україномовне книговидання, аудіо- та відеопродукцію, програмне забезпечення» (Кошулинський,2019, с. 2).

«На телебаченні, радіо, в друкованій пресі єдина державна українська мова має домінувати», - проголошує у свойй передвиборчій кампанії В. Купрій (Купрій, 2019, с. 4).

Аналогічної позищії додержується кандидат в Президенти України В. Кривенко: «Українська мова - основа безпеки, вона об'єднає суспільство й стане мовою міжнаціонального спілкування в Україні. При наданні громадянства України, а також при прийомі на роботу, пов' язану з публічною інформацією, незалежно від форми власності підприємства, буде проводитися обов' язкове тестування на підставі визначених державних стандартів української мови. Навчальновиховний процес у державних та комунальних освітніх закладах повинен здійснюватися винятково державною українською мовою» (Кривенко, 2019, с. 2).

Увага приділена мовній політиці держави також у передвиборній програмі П. Порошенка. Він обіцяє: «Ми захищаємо свою мову, вкладаємо кошти у підтримку української культури. Продовжимо політику підтримки української мови як єдиної державної. Розширимо підтримку культурних проектів - кіно, музики, книги та інших напрямів. Буде підтримано розвиток місцевих закладів культури, які стануть сучасними центрами розвитку громад. Сприятимемо залученню до роботи в українських школах носіїв англійської мови» (Порошенко, 2019, с. 3).

Підсумовуючи розгляд програм вищевказаних кандидатів на предмет мовного питання, можемо констатувати, що вони намагаються завоювати і заручитися підтримкою патріотичного електорату через заклики до захисту української мови. 
3 іншого боку у передвиборчому дискурсі чітко окреслилася група кандидатів, які, навпаки, намагаються завоювати виборця, акцентуючи увагу на наданні офіційного статусу другій мові. Це - Ю. Бойко, якій у своїй програмі обіцяє, що поверне право громадян навчатися рідною мовою (Бойко, 2019, с. 4), О.Вілкул, який висуває у своїй програмі такі тези: «Державна мова - українська. Обласні ради можуть запроваджувати в області другу офіційну мову. Автономія регіонів у гуманітарній, культурній і мовній політиці» (Вілкул, 2019, с. 3) та ін.

Деякі кандидати включають мовне питання у більш ширший світовий та культурний контекст. Зокрема Р. Насіров обіцяє: «Безкоштовні державні програми із вивчення англійської мови молоді та всіх, хто бажає вивчати англійську» (Насіров, 2019, с. 5).

В програмі Ю. Тимошенко окремо про мову як об'єкт державної політики не йдеться, але в частині, присвяченій українській культурі, вона наголошує: «Фінансування культурного та духовного розвитку народу, збереження та примноження його культурної спадщини буде одним із пріоритетних напрямів спрямування державних коштів. Буде розгорнуто потужні центри присутності української культури за кордоном. Буде надаватися державна підтримка для фінансування перекладів іноземними мовами найкращих творів української літератури, їх видання та розповсюдження по світу» (Тимошенко, 2019, с. 5).

А. Гриценко у свої передвиборчій програмі наголошує: «Не будуть обмеження і покарання визначальними в розвитку української культури і мови - будуть стимули для виробництва українських культурних шедеврів, насамперед українського кіно, книговидавництва, сучасних проектів для підлітків і молоді» (Гриценко, 2019, c. 5).

Позицію по мовному питанню також висловив у передвиборчому дискурсі кандидат на пост Президента України В. Зеленський, який в одному з своїх інтерв'ю підкреслив, що «згідно з Конституцією, державною мовою є українська і має нею залишатися, проте влада повинна гарантувати вільний розвиток і використання інших мов. Українська мова - чудова мова, коли на ній говорять грамотно і красиво, це приголомшливо. Всі й так переходять на українську мову 3 великим задоволенням» (Не треба тиснути російську мову: Зеленський розповів своє бачення мовного питання в Україні, 2019).

Висновки. Мовне питання є й досі обов' язковим складником ідеологічної риторики різних політичних сил, порушується переважно 174 
в періоди перед виборами і є частиною низки виборчих програм кандидатів, хоча його роль і дещо змінилася у зв' язку зі склавшоюся ситуацією в Україні. Для більшості кандидатів, що виступають 3 пропозиціями щодо змін у державній мовній політиці, підняття проблеми мови, швидше за все, лише певний спосіб позиціювання себе у рамках традиційної для України системи координат. Втім, на нашу думку, основним засобом впливу на мовну ситуацію в країні могла би стати оновлена та раціональна мовна політика, яка б надала державній мові привабливості і не несла б примусового характеру.

\section{Лiтература:}

Бабицкий К. Э. (2007). Пихологические особенности избирательных кампаний. MOCУ, 4.

Борухович А. С. (2008). Сучасна мовна політика: ситуація в Україні. Державне будівництво, 2, 9.

Власенко Д. (2018). Конституційно-правове регулювання мовних відносин в Україні. Права Людини в Україні. <http://khpg.org/index. php?id=1527068382>.

Євсєєва Г. П. (2009). Мова як чинник національної самоідентифікації та державотворення в Україні. Державне управління та місцеве самоврядування: 3б. наук. праць, Вип. 1, 3-13.

Закон про засади державної мовної політики від 2013р. № 23 (Верховна Рада України). <https:/ zakon.rada.gov.ua/laws/show/5029-17>.

Кирилюк Ф. М. (2004). Політологія. Навч. посібник. К.: Здоров'я.

Конституиія України від 28 червня 1996 р. (Верховна Рада України). Відомості Верховної Ради України, 30, 141.

Не треба тиснути російську мову: Зеленський розповів своє бачення мовного питання в Україні (2019). Українські новини, 21 березня, четвер. <https://ukranews.com/ua/news/621259-ne-treba-tysnutyrosijsku-movu-zelenskyj-rozpoviv-svoye-bachennya-movnogo-pytannyav-ukrayini>.

Передвиборча програма кандидата на пост Президента України B. Кривенка. Центральна виборча комісія: офіційний веб-сервер. <https://www.cvk.gov.ua/pls/vp2019/wp005pt021f01=264pt001f01= 720.html>.

Передвиборча програма кандидата на пост Президента України О. Вілкула. Центральна виборча комісія: офіційний веб-сервер. 
<https://www.cvk.gov.ua/pls/vp2019/wp005pt021f01=224pt001f01= 720.html>.

Передвиборча програма кандидата на пост Президента України P. Насірова. Центральна виборча комісія: офіційний веб-сервер. <https://www.cvk.gov.ua/pls/vp2019/wp005pt021f01=213pt001f01= 720.html>.

Передвиборча програма кандидата на пост Президента України Ю. Бойка. Центральна виборча комісія: офіційний веб-сервер. <https:/ / www.cvk.gov.ua/pls/vp2019/wp005pt021f01=216pt001f01= 720.html>.

Передвиборча програма кандидата на пост Президента Украӥни Ю. Тимошеко. Центральна виборча комісія: офіційний веб-сервер. <https://www.cvk.gov.ua/pls/vp2019/wp005pt021f01=225pt001f01= 720.html>.

Передвибориа програма кандидата у Президенти України B. Купрія. Центральна виборча комісія: офіційний веб-сервер. <https:/ / www.cvk.gov.ua/pls/vp2019/wp005pt021f01=206pt001f01= 719.html>.

Передвиборча програма кандидата у Президенти України П. Порошенка. Центральна виборча комісія: офіційний веб-сервер. <https://www.cvk.gov.ua/pls/vp2019/wp005pt021f01=295pt001f01= 720.html>.

Передвиборча програма кандидата у Президенти України Р. Кошулинського. Центральна виборча комісія: офіційний веб-сервер. <https:/ / www.cvk.gov.ua/pls/vp2019/wp005pt021f01=228pt001f01= 719.html>.

Предвиборча програма кандидата на пост Президента України А. Гриценка. Центральна виборча комісія: офіційний веб-сервер. <https://www.cvk.gov.ua/pls/vp2019/wp005pt021f01=208pt001f01= 720.html>.

Про державну мовну концепиію: Указ Президента України від 15 лютого 2010 p. № 161/ 2010 (Президент України). <http:/ / zakon2.rada.gov.ua/ laws/show/161/2010>.

Про забезпечення функціонування української мови як державної: Проект Закону від 07 лютого 2019 №2679-VIII (Верховна Рада України). <http:/ / w1.c1.rada.gov.ua/pls/zweb2/webproc4_1?pf3511=61994>.

Про затвердження Комплексних заходів щзодо всебічного розвитку $i$ функціонування украӥнської мови: Постанова Кабінету міністрів 
України від 8 вересня 1997 р. № 998 (Кабінет Міністрів України). <https://zakon.rada.gov.ua/laws/show/998-97>.

Про Положення про Раду з питань етнонаціональної політики: Указ Президента України від 18 липня 2006 року № 625/2006 (Президент України). <https:/ / www.president.gov.ua/documents/6252006-4593>.

Семенов В. М. (2010). Історичні витоки мовної регіоналізації. Актуальні проблеми державного управління: зб. наук. пр. Х.: Вид-во Хар.РІ НАДУ «Магістр», № 2 (38), 204-209.

Халипов В. Ф., Халипова Е. В., Шишкин А. Н. (1993). Выборы и власть: Словарь-справочник избирателя. М.: Совершенство.

\section{References:}

Babytskyi K. E. (2007). Pykholohycheskye osobennosty yzbyratelnukh kampanyi [Psychological features of election campaigns]. MOS [MOS], 4. [in Russian].

Borukhovych A. S. (2008). Suchasna movna polityka: sytuatsiia v Ukraini [Modern linguistic politics: the situation in Ukraine]. Derzhavne budivnytstoo [State building], 2, 9. [in Ukrainian].

Khalypov V. F., Shyshkyn A. N. (1993). Vibori y vlast: Slovar-spravochnyk izbyratelia [Elections and Power: Vocabulary Dictionary] M.: Sovershenstvo. [in Russian].

Konstytutsiia Ukrainy vid 28 chervnia 1996 r. (Verkhovna Rada Ukrainy) [The Constitution of Ukraine (Verkhovna Rada of Ukraine)]. Vidomosti Verkhovnoi Rady Ukrainy [Bulletin of the Verkhovna Rada of Ukraine], 30, 141. [in Ukrainian].

Kyryliuk F. M. (2004). Politolohiia. Navch. posibnyk [Political science. Study manual]. K.: Zdorovia. [in Ukrainian].

Ne treba ty`snuty`rosijs `ku movu: Zelens`ky`j rozpoviv svoye bachennya movnogo py`tannya v Ukrayini [There is no need to press Russian: Zelensky told his vision of the language issue in Ukraine] (2019). Ukrayins 'ki novy 'ny [Ukrainian News], 21 bereznya, chetver. <https://ukranews.com/ua/ news/621259-ne-treba-tysnuty-rosijsku-movu-zelenskyj-rozpoviv-svoyebachennya-movnogo-pytannya-v-ukrayini>. [in Ukrainian].

Predyborcha prohrama kandydata na post Prezydenta Ukrainy A. Hrytsenka [Preelection program of the candidate for President of Ukraine A. Hrytsenka]. Central na vy borcha komisiya: oficijny $j$ veb-server [Central Election Commission: official web server]. <https:/ / www.cvk.gov.ua/pls/vp2019/ wp005pt021f01 $=208$ pt001f01 $=720 . h t m l>$. [in Ukrainian]. 
Predyborcha prohrama kandydata na post Prezydenta Ukrainy O. Vilkula [Pre-election program of the candidate for President of Ukraine O. Vilkula]. Central 'na vy borcha komisiya: oficijny j veb-server [Central Election Commission: official web server. <https:/ / www.cvk.gov.ua/pls/vp2019/ wp005pt021f01 $=224$ pt001f01 $=720 . h t m l>$. [in Ukrainian].

Predyborcha prohrama kandydata na post Prezydenta Ukrainy R. Nasirova [Pre-election program of the candidate for President of Ukraine R.Nasirova]. Central na vy borcha komisiya: oficijny j veb-server [Central Election Commission: official web server]. <https://www.cvk.gov.ua/ pls/vp2019/wp005pt021f01=213pt001f01 =720.html>. [in Ukrainian].

Predyborcha prohrama kandydata na post Prezydenta Ukrainy V. Kryvenka [Pre-election program of the candidate for President of Ukraine V. Kryvenka]. Central'na vy borcha komisiya: oficijny j veb-server [Central Election Commission: official web server]. <https:/ / www.cvk.gov.ua/ pls/vp2019/wp005pt021f01=264pt001f01=720.html>. [in Ukrainian].

Predyborcha prohrama kandydata na post Prezydenta Ukrainy Yu. Boiko. [Pre-election program of the candidate for President of Ukraine Y. Boyko]. Central `na vy borcha komisiya: oficijny j veb-server [Central Election Commission: official web server]. <https:/ / www.cvk.gov.ua/pls/vp2019/ wp005pt021f01 $=216$ pt001f01 $=720 . h t m l>$. [in Ukrainian].

Predyborcha prohrama kandydata na post Prezydenta Ukrainy Yu.Tymosheko [Pre-election program of the candidate for President of Ukraine J.Tymosheko]. Central na vy borcha komisiya: oficijny jo veb-server [Central Election Commission: official web server]. <https:/ / www.cvk.gov.ua/ pls/vp2019/wp005pt021f01=225pt001f01=720.html>. [in Ukrainian].

Predyborcha prohrama kandydata u Prezydenty Ukrainy P.Poroshenka [Pre-election program of the candidate for President of Ukraine P.Poroshenka]. Central na vy borcha komisiya: oficijny j veb-server [Central Election Commission: official web server]. <https://www.cvk.gov.ua/ pls/vp2019/wp005pt021f01=295pt001f01=720.html>. [in Ukrainian].

Predyborcha prohrama kandydata u Prezydenty Ukrainy R. Koshulynskoho [Pre-election program of the candidate for President of Ukraine R. Koshulynskoho]. Central na vy borcha komisiya: oficijny ’j veb-server [Central Election Commission: official web server]. <https:/ / www.cvk.gov. $\mathrm{ua} / \mathrm{pls} / \mathrm{vp} 2019 / \mathrm{wp} 005 \mathrm{pt021f01=228pt001f01=719.html>}$. [in Ukrainian]. Predyborcha prohrama kandydata u Prezydenty Ukrainy V. Kupriia [Pre-election program of the candidate for President of Ukraine 
V. Kupriia]. Central na vy borcha komisiya: oficijny’j veb-server [Central Election Commission: official web server]. <https:/ /www.cvk.gov.ua/ pls/vp2019/wp005pt021f01=206pt001f01=719.html> (2019, March,18) [in Ukrainian].

Pro derzhavnu movnu kontseptsiiu: Ukaz Prezydenta Ukrainy № 161 (Prezydent of Ukraine) [On the State Language Concept: Decree of the President of Ukraine (President of Ukraine)]. <http://zakon2.rada.gov.ua/laws/ show/161/2010>. [in Ukrainian].

Pro Polozhennia pro Radu z pytan etnonatsionalnoi polityky: Ukaz Prezydenta Ukrainy №625 (Prezydent Ukrainy) [On the Regulations on the Council on the Issues of Ethnonational Policy: Decree of the President of Ukraine № 625 (President of Ukraine)]. <https:/ / www.president.gov. ua/documents/6252006-4593>. [in Ukrainian].

Pro zabezpechennia funktsionuvannia ukrainskoi movy yak derzhavnoi: Proekt Zakonu №2679-VIII (Verkhovna Rada Ukrainy) [On ensuring the functioning of the Ukrainian language as a state:DraftLaw (Verkhovna Rada of Ukraine)]. <http://w1.c1.rada.gov.ua/pls/zweb2/ webproc4_1?pf3511=61994>. [in Ukrainian].

Pro zasady derzhavnoi movnoi polityky: Zakon Ukrainy №23 (Verkhovna Rada Ukrainy) [On the principles of state language policy: Law of Ukraine №23 (Verkhovna Rada of Ukraine)]. <https:/ / zakon.rada.gov.ua/laws / show/5029-17>. [in Ukrainian].

Pro zatverdzhennia Kompleksnykh zakhodiv shchodo vsebichnoho rozvytku $i$ funktsionuvannia ukrainskoi movy: Postanova Kabinetu ministriv Ukrainy № 998 (Kabinet ministriv Ukrainy) [On Approval of Comprehensive Measures for the Comprehensive Development and Functioning of the Ukrainian Language: Resolution of the Cabinet of Ministers of Ukraine № 998 (Cabinet of Ministers of Ukraine)]. <https:/ / zakon.rada.gov.ua/ laws/show/998-97>. [in Ukrainian].

Semenov V. M. (2010). Istorychni vytoky movnoi rehionalizatsii [Historical origins of language regionalization]. Actual problems of public administration [Actual problems of public administration: Coll. Sciences]. X.: Vy`d-vo Xar.RI NADU “Magistr”, 2 (38), 204-209. [in Ukrainian].

Vlasenko D. (2018). Konsty`tucijno-pravove regulyuvannya movny`x vidnosy`n v Ukrayini [The constitutional and legal regulation of language relations in Ukraine]. Prava Lyudy 'ny v Ukrayini [Human Rights in Ukraine]. <http:/ / khpg.org/index.php?id=1527068382>. [in Ukrainian]. 
Yevsyeyeva G. P. (2009). Mova yak chy`nny`k nacional`noyi samoidenty`fikaciyi ta derzhavotvorennya v Ukrayini [Language as a factor of national self-identification and state formation in Ukraine]. Derzhavne upravlinnya ta misceve samovryaduvannya: Zb. nauk. pracz' [Public administration and local self-government: Coll. Sciences. works], Vy`p. 1, 3-13. [in Ukrainian].

\section{Анотація}

Веремчук О.О. Місце та роль мовного питання у виборчій кампанії 2019 р. в Украйні. - Стаття.

Висвітлюється проблематика мовного питання $b$ політичному дискурсі, його актуальність та місце в передвиборчих програмах кандидатів на виборах 2019 року. Проаналізована ситуація, яка склалася навколо мовної політики в попередні роки та ї̈ місие в передвиборчих програмах 2019 року. Розглянуті такі категорії як «виборчі технологї», «мовна політика», «передвиборча програма». 3'ясовано, що мовне питання ӥ досі є актуальним та не зникає з порядку денного української політики, хоча його роль і дещо змінилася.

Ключові слова: мовна політика, мовне питання, виборчі технології, виборча кампанія, передвиборча програма кандидата. 